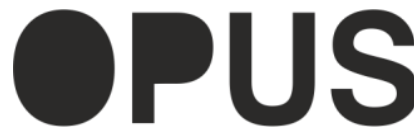

Uluslararası Toplum Araştırmaları Dergisi International Journal of Society Researches
E-ISSN : 2528-9535

YIl Year: 10

Cilt Volume: 16

Sayı Issue :Eğitim ve Toplum Özel Sayısı

Aralık December 2020

Makalenin Geliş TarihiReceived Date:10/04/2020

Makalenin Kabul Tarihi Accepted Date: 24/11/2020

\title{
Muhafazakâr Bir Düşünür Olarak Topçu'nun Demokrasi Yaklaşımı
}

\author{
DOI: 10.26466/opus.718211
}

*

\section{Yunus Koç*}

*Dr. Öğretim Üyesi, Muş Alparslan Üniversitesi, İktisadi ve İdari Bilimler Fakültesi, Siyaset Bilimi ve Kamu Yönetimi Bölümü, Muş/Türkiye

Öz

E-Posta: yunuskoc2@hotmail.com

ORCID: 0000-0001-9453-2910

Topçu, sonsuz ihtirasların, sefaletlerin, haksızlikların ve düşmanlıklarm, maddenin (bedenin) hâkimiyetinin sonucu olduğuna inanmaktadır. Ruhu ise, bütün yüce değerleri harekete geçiren, insanı sonsuzluk âlemlerine kanatlandıran, ilimde, iktisatta, sanatta, kültürde ve daha birçok sahada insani olanı ilahi olanla buluşturarak kalbin ve kafanın imtizacını sağlayan bir güç olarak değerlendirmektedir. Diğer bir ifadeyle madde, çocuksu ilkel heveslerin, şımarık ve nefsanî ihtirasların, şehvet ve şöhretin; ruh ise, insanı hamlıktan olgunluğa yükselten, aşk ve ıstırabın, kalp ve kafanın yatağıdır. Tam da bu minvalden yola çıkarak diyebiliriz ki, Nurettin Topçu'nun demokrasi eleştirilerinin de merkezinde madde-ruh kavramları vardır. Bu açıdan Topçu'nun demokrasinin temel umdeleri olan eşitlik, hürriyet, seçim, oy, temsil, genel irade ve ortak çıkar kavramlarına olan yaklaşımını incelemek ve ne tür ideal bir rejim tahayyül ettiğ̈ini irdelemek çalışmanın amacını oluşturmuştur. Bu amaç çerçevesinde içerik analizi yöntemine uygun olarak Topçu'nun temel eserleri incelenmiş, eserlerden çıkarılan temel kavramlar irdelenmiş, elde edilen veriler anlaşılmaya, tanımlanmaya ve bu verilerden çıkarımlar yapılmaya çalışılmıştır.

Anahtar Kelimeler: $\quad$ Demokrasi, Irade Rejimi, Madde, Ruh 


\title{
As a Conservative Philosopher Topçu's Approach to the Democracy
}

\begin{abstract}
Topçu, believes that endless passions, misery, injustice and hostility are the result of the domination of matter (body). On the other hand, he characterizes the soul as a force that activates all the supreme values and envelops humanity into the realms of eternity and a force that provides the harmony of the heart and the mind by bringing the human to the divine in science, economics, art, culture and many other fields. In other word, matter is the bed of childish primitive desires, sassy and selfish ambitions, lust and fame and the soul is the bed of love and suffering, the heart and the head, which raises man from rawness to maturity. In this manner, we can say that the concepts of matter and soul is placed at the center of Nurettin Topçu's criticisms of democracy are the concepts of matter and soul. In this respect, the aim of this study is to examine the approach of Topçu to the concepts of equality, liberty, election, vote, representation, general will and common interest, which are the main principles of democracy, and to examine what kind of ideal regime he has imagined.In accordance with this purpose, the main studies of Topçu were examined within the content analysis method, the basic concepts extracted from his studies were examined, the obtained data are tried to be understood, defined and inferences are made from these data.
\end{abstract}

Keywords: Democracy, Regime of Will, Matter, Soul 


\section{Giriş}

Avrupa'da muhafazakârlık; siyasi, sosyal, ekonomik-kültürel altüst oluşların neticesinde ortaya çıkmış bir tür reaksiyon ideolojisi şeklinde değerlendirilebilir. Muhafazakârlık; inkılâpçı ve devrimci itmelere karşı mukavemet gösteren sınıfların ve yapıların direnç noktasını oluşturur. Burjuvazinin öncülügü̈nde tesis edilmeye çalışılan yeniliklere karşı, aşınan değerlere, tasfiye edilmek istenen kurumlara sahip çıkma endişesinin muhafazakârlığı besleyen temel saik olduğu ileri sürülebilir. Muhafazakârlık ideolojisinin evrensel ölçekte birtakım müşterek çizgilere sahip olduğu bilinmekle birlikte, bu ideolojinin, farklı tarihsel-toplumsal zeminlerde farklı renklere büründüğü görülmektedir. İngiliz tipi muhafazakârlık ile Fransız tipi muhafazakârlık arasındaki benzerlikler ve farklar bu toplumların modernleşme deneyimlerindeki sınıfsal konfigürasyonlarla açıklanabilir. Fransız örneğinde burjuvazi köylülükle ittifak kurarak iktidara yürümüş ve aristokrasiyi neredeyse iktidar alanının dışına itmiştir. Geleneksel değerlerin taşıyıcısı konumunda bulunan aristokrasinin sözcülüğünü üstlendiği muhafazakârlığın Fransız tipi yorumunun radikal nitelikler taşıması bu açından doğal karşılanmalıdır. Buna mukabil, İngiltere'de burjuvazi aristokrasinin büyük bir kısmıyla ittifak kurarak yeni bir elit sınıf yaratmış ve aristokrasiyi doğrudan karşısına almamıştır. Bu durumun İngiliz tipi muhafazakârlığı Fransız tipi muhafazakârlığa kıyasla daha mutedil kıldığı söylenebilir (Moore, 2016).

Türkiye'de ise muhafazakârlığı belirli bir sınıfsal temele oturmak için elimizde yeterli kanıt yoktur. Modernleşme vetiresi boyunca geleneksel değerleri ülkenin geri kalışının temel sebebi olarak değerlendiren Cumhuriyetçi elite karşı ileri sürülen itirazların Türk tipi muhafazakârlığın kaynağını oluşturduğu düşünülebilir. Tam da bu noktada muhafazakâr bir Türk düşünür olarak Nurettin Topçu'nun, idealist bir felsefeyle madde ruh ekseninde demokrasiye olan yaklaşımı önem arz etmektedir.

Bu bağlamda çalışmada ilk olarak, muhafazakâr düşüncenin demokrasiye olan yaklaşımları irdelenecektir. İkinci olarak, Nurettin Topçu'nun demokrasi hakkındaki düşünceleri ele alınacaktır. Son olarak, Topçu'nun demokrasiyi irdeleyerek nasıl bir yönetim tahayyül ettiği incelenecektir.

Çalışmanın amacı muhafazakâr bir düşünür olarak Topçu'nun demokrasi rejimini temel umdeleri ile nasıl değerlendirdiğini ve ne tür ideal bir 
yönetim biçimini savunduğunu ortaya koymaktır. Bu amaç çerçevesinde içerik analizi yöntemine (Koçak ve Arun, 2006) uygun olarak Topçu'nun temel eserleri incelenmiş, eserlerden çıkarılan temel kavramlar irdelenmiş, elde edilen veriler anlaşılmaya, tanımlanmaya ve bu verilerden çıkarımlar yapılmaya çalışılmıştır.

\section{Muhafazakâr Düşüncenin Demokrasiye Yaklaşımı}

Muhafazakârlık, bir fikir ve doktrin olarak ilk kez 18. yy'ın sonları ve 19. yy'ın başlarında ortaya çıkmıştır. Bilhassa Fransız devrimiyle meydana gelen sosyal, siyasal ve ekonomik değişimlere gösterilen tepkiler muhafazakârlı̆̆ın ruhunu oluşturmuştur. Bu açıdan muhafazakârlık, eski düzene geri dönüş isteği şeklinde yorumlanabilir. Muhafazakârlığın temel kaygısı, geleneksel ve toplumsal değerlerin korunmasıdır. Bu zaviyeden ele alınd1ğında tek bir muhafazakârlıktan söz edilemeyeceği söylenebilir. Keza Joseph de Maistre'nin liderliğindeki Kıta Avrupa'sı muhafazakârlı̆̆ı, reform fikrine ve değişime karşıyken "muhafaza etmek için değiştirmek" fikrini öne süren Anglo-Amerikan muhafazakârlığın öncüsü Edmund Burke ise; devlet idaresinin yönetimini, akla dayanarak yaratılacak soyut kurumlarda değil devletin uzun dönemden beri gelen, deneyimlerle oluşan yapılarda mesela aile ve kilise gibi kurumlarda aramak gerektiğini düşünmüştür. Bu yüzden değişim olacaksa da ancak devrimsel olmaktan ziyade organik yani kendi için doğal ve yavaş olması gerekliydi. Yani Burke, sosyal ya da siyasal hayatın baştan aşağı, Fransız ihtilalının getirdiği özgürlük, eşitlik ve kardeşlik gibi soyut ilkelere göre yeniden düzenlenmesini eleştirmiş bunun yerine deneyime, geleneğe ve tarihe özel bir önem vermiştir (Aytaç, 2014, s.117119; Köni, Nişanc1, 2018, s.62-69).

Yeni sağı oluşturan ana öğelerden biri olan neo-muhafazakârlık da, 19.yy muhafazakârlı̆̆ın ilkeleri üzerine oturmuştur. Asıl gayesi; otoriteyi sağlamak için aile, din, ${ }^{1}$ millet gibi kültürel kodlara yönelmektir. Tahayyül ettiği otorite, geleneksel değerlere sadakati, içtimai düzeni ve disiplini sağlayacak

\footnotetext{
${ }^{1}$ Din toplumsal düzeni, sınıflar arasındaki ilişkiyi sağlamak, bireyin toplumsal uyumunu sağlayacak ahlaki değerleri vermek açısından önemli görülür. Dolayısıyla gelenekselci muhafazakârlığın teokratik devlet anlayışının dışında modern muhafazakârlıkta din ve siyaset birbirinden bağımsız ve toplumsal düzen için hayati öneme sahiptir. Aynı zamanda dinin siyasetin işleyişini güçlendirecek işlevsel bir nitelik taşıdığı düşünülür (Köni ve Nişancı, 2018, s.68).
} 
bir güç olduğu için neo-muhafazakârlık otorite karşısında bireye kendi seçimlerini yapma hakkını veren özgürlükçü düşünceye düşmandır. Neomuhafazakârlığın diğer önemli hususiyeti, birden fazla kültürü ve dini içinde barındıran toplumsal yapılara kaygı ile yaklaşır. Keza böylesi yapıların, istikrarsızlık ve çatışma riski getireceği düşünülür. Bu açıdan neomuhafazakârlık milliyetçi ideolojiye oldukça yakındır (Türk, 2003, s.125). Bir ideoloji halini almasını, 19.yy muhafazakârlı̆̆ın önceki muhafazakâr tutumdan farklılık arz etmesiyle açıklamak mümkündür (Aytaç, 2014, s.116). Mannheim'in dediği gibi, muhafazakârlık gelenekselci ya da doğal muhafazakârlık olarak tarif edilirken neo-muhafazakârlık, modern muhafazakârlıktır. Bu muhafazakârlık, geleneksel düşüncenin modernleşme süreciyle birlikte bilinçli bir hal almış olmasını, dönemin koşulları ile ilişki kurmasını ve ihtilal karşıtı durumu ifade eder. Böylece hayatı, muhakeme etmeden geleneksel, mistik şekliyle idrak eden önceki anlayışa karşın muhafazakârlık, artık kendisini aklın muhakemesinden geçirecek hale gelir. Bu çaba, muhafazakâr düşüncenin ideolojik bir hal almasına neden olur (Güler, 2012, s.118). Fakat muhafazakârlar; sahip olduğu düşünce sistemini, ideoloji olarak görmezler daha ziyade yaşama yönelik bir duruş şeklinde tanımlarlar (Aytaç, 2014, s.116).

Muhafazakârlığın savunduğu temel değerler dikkate alındığında demokrasinin özgürlük, eşitlik ve genel irade gibi temel ilkelerine oldukça mesafeli olduğunu söylemek mümkündür (Honderich, 2005; Beneton, 2011). Muhafazakâr düşünceye göre, insan yaşamının çelişkiler, ikilemler ve gerilimler içermesi sınırların oluşmasına neden olur. Bunlar ruh-madde, insan-doğa, birey-toplum ve yöneten-yönetilen gibi hiçbir zaman tümüyle ortadan kaldırılamayan ikilemlerdir. İşte bu sınırlar, muhafazakârlığın düzene ilişkin doktrin anlayışını gösterir (Güler, 2012, s.119). Tasavvur edilen düzen, demokrasinin sunduğu değerleri de sinırlayan hatta yeri geldiğinde yok sayan bir düzendir.

Demokrasi; halk iradesini, yönetimin ana grizgahı ve güven telkin eden bir doktrin olarak sunmasına karşın muhafazakârlık, genel iradeyi bir yıkım olarak değerlendirir. Bunun insan doğasına yaklaşım tarzları arasındaki farklılıkla ilişkili olduğu söylenebilir. Öyle ki demokrasinin aksine muhafazakârlık, Hıristiyanlığın "ilk günah" doktrinini benimseyerek insanın doğuştan iyi ve özgür olmadığı kanısındadır. Böylece iyi olmayan insanın, kendi arzularını bir tarafa bırakıp genel irade adı altında toplumun iyiliğini 
sağlaması da beklenemez (Şeyhanhığlu, 2011, s.96; Akkaş, 2003, s.243). Hatta Burke, yapay bir oluşum olan genel iradede hem bireyin hem de toplumun idrak gücünün zayıf olduğunu belirtmiştir. Doğal sürecinden koparılmayarak, yaşayan bir organizma olarak ele alındığında ise birey ve toplum kendi anlam dünyasına ulaşacağını ve yapıcı bir nitelik taşıyacağını vurgulamıştır (Burke, 2016). Yeri gelmişken söylemek gerekir ki, muhafazakârların çıkış noktası birey değil toplumdur. Toplum ise, maddi ve sosyolojik temele dayanan, bu yönüyle analiz edilen toplum değil Tanrının yarattığ1 toplumdur. Toplumun amacı da, bireysel özgürlüğü sağlamak değil kaynağı Tanrı olan siyasal otoriteyi, kadim kurumları ve aileyi korumaktır. Çünkü bunlar, toplumun bütünlüğünü sağlarlar. Zaten birey ile toplum arasında ilişkiyi sağlayan da bu kadimliktir. Dolayısıyla muhafazakâr düşünceye göre, genel iradeye dayanarak bireyin, rasyonel ve özgür bir şekilde toplumun iyiliğini gözetemeyeceğini ancak iyi tanzim edilmiş bir devlette bağlllık, vatanperverlik, mütedeyyinlik gibi ilkelerle ve erdemlerle sinırlandırıldığı takdirde bunu gerçekleştirebilir. Bu yüzden muhafazakârlık, insanın ahlaki mesuliyetlerinden soyutlanarak yalnızca aklın potasında eritilme düşüncesine karşıdır (Güler, 2012, s.121-132).

Muhafazakârlara göre, politikanın kendisi; devleti tanzim edecek bilimden, evrensel düzeyde uygulayabileceği politik ideallerden veya mücerret insan haklarından yoksundur. Bundan dolayı muhafazakârlar, genel oy hakkı ile sembolize edilen demokrasiye, ferdiyetçiliğe, müsavat, hürriyet ve halk egemenliği prensiplerine karşıdırlar. Mücerret haklara ve sözleşmeye müstenit rasyonel toplum düşüncesine mukabil kadim olan içtimai nizamı, cemiyeti, gelenekleri, hayat tarzını temel alarak toprağın, ailenin ve dinin savunuculuğunu yaparlar (Türk, 2003, s.122-123; Güler, 2012, s.122-125; Aytaç, 2014, s.117). Muhafazakâr düşüncede, bireysel ya da toplumsal eşitlik savunulmadığı gibi siyasal eşitlikten söz edildiğinde de aynı düzeye getirilmeye çalışanlar, asla eşitlenemezler inancı vardır. Eşitlik olmayacağına göre toplumun farklı gruplara ve sınıflara ayrılmış olması da doğaldır. Hatta bu farklılıklar istikrarlı bir toplumun devamı açısından gereklidir (Aytaç, 2014, s.118; Güler, 2012, s.135-137). Burke'nin de dediği gibi siyasi, sosyal ya da ekonomik eşitlik doğal değildir, canavarca bir kurgudur, toplumda korkunun oluşmasında etkilidir ve düzene karşıdır. Bundan dolayı yazar için iyi bir demokrasi, korkulması gereken en kötü yönetimdir (Burke, 2016). Ayrıca muhafazakâr düşüncede, demokrasinin temel iki ilkesi olan 
özgürlük ve eşitlik birbirleri ile uyumlu görülmez. Özgürlük toplumsal eşitsizliğinde kaynağı olarak kabul edilir. Hatta özgürlük, insanlık için zorunlu bir hak olarak kabul edilmez. Özgürlük; aile, cemaat ya da yerellik bazında desteklenmeden hayata geçirilmez. Diğer bir ifadeyle özgürlük, kadim toplumsal değerlerin, kurumların, ailenin ve düzenin korunması ile sinırlıdır (Güler, 2012, s.126-138; Uluçakar, 2018, s.356-360).

Muhafazakâr düşüncede genel olarak; din, toplum, birey, düzen ve siyasal otorite kavramları arasında önemli ilişki söz konusudur. Siyasal otorite, toplumsal düzeni yalnızca kurumlarla gerçekleştiremez. Otorite, kendisine bu gücü sağlayacak, topluma ve bireye itaat kültürünü verecek dine ihtiyaç duyar. Bu yüzden muhafazakârlar, iyi bir yönetim anlayışından ziyade daha genel bir çerçeve çizen farklı tasavvurlar ortaya koyarlar. Keza geleneği terakkinin önündeki en büyük engel olarak gören Cumhuriyetçi elitlere karşın Türkiye'de muhafazakâr düşünürler mütecanis bir tasavvura sahip olmadıkları söylenebilir. Bir başka ifadeyle muhafazakârlığın tarihsel seyrini dikkate alan düşünürler, Türkiye bağlamında geçirdiği dönüşümü açıklamak üzere farklı kavramlar, kuramlar, metotlar üretmişlerdir. ${ }^{2}$ Tam da bu noktada muhafazakâr bir düşünür olarak Nurettin Topçu'nun demokrasi rejimine olan yaklaşımının nasıl olduğu önem arz etmektedir.

\section{Nurettin Topçu ve Demokrasi}

Topçu, herhangi bir siyasal sistemi madde-ruh merkezli perspektif ile kritik etmekte, bir yönetim biçimini, bireyi ve toplumu ruhen yükseltmek kaydıyla takdire şayan bulmaktadır. Her ne kadar; "hiçbir rejim kendiliğinden mutlak surette ne iyidir ne de fenadir; esas olan onu kullanacak insanin ruh ve ahlak yapıstdir" (Topçu, 2014a, s.124) sözleriyle, demokrasi türü rejimleri birer vasita olarak gördügünü ihsas etmekte ve kullanıcıların ruhsal ve ahlaki seviyesine göre kıymetlendirmekte ise de, demokrasiye içkin olduğunu düşündüğü birtakım arızalara dikkat çekmektedir. Yazarın, "bir içtimai fikir veya hareketin değeri onun ruhları kurtarncı oluşuyla ölçülür" (Topçu, 2014a, s.203-204) ifadesi,

\footnotetext{
${ }^{2}$ Bunlardan temel öneme haiz "tekno muhafazakârlık" kavramı için bkz. Mollaer, F. (2016). Tekno Muhafazakârlığın Eleştirisi: Politik Denemeler, Iletişim Yayınları. Ayrıca tekno muhafazakârlığın eleştirel bir figürü olarak aynı yazarın "Liberal Muhafazakârlık Karşısında Nurettin Topçu” kitabına bakınız.
} 
"demokrasi her yerde cemiyetin istek ve iştihalarmı harekete geçirdi" (Topçu, 2017, s.43) yargisıyla bir arada düşünülmelidir.

Topçu; demokrasiyi eşitlik, hürriyet, seçim, oy, temsil, çoğunluğun yönetimi, genel irade gibi ana düsturları üzerinden tartısmaktadır. Yazarın bu ilkelere yaklaşımını ele alarak nasıl bir rejim tahayyülü içerisinde olduğunu anlamak açısından da önem arz etmektedir.

\section{Eşitlik - Hürriyet}

Hürriyet ve eşitliği demokrasinin iki temel rüknü olarak gören Topçu (2013, s.104), hürriyetin "vatandaşlarm başkasına zarar vermemek kaydryla her şeyi yapabilmesi", eşitliğin ise "başkalarımın bizimle eşit haklara sahip olduğunun ikrarı" şeklinde anlaşıldığını belirtmektedir. Demokrasinin taşıyıcı sütunları olan eşitlik ve özgürlük kavramlarını madde-ruh merceğinden kritik ederek mezkûr kavramların demokrasi içi anlamlandırmalarına karşı çıkmaktadır. Hürriyetin, hiçbir zaman ruhi ve ahlaki hürriyet manası (Topçu, 2014a, s.134) kazanmadığını düşünmektedir.

Topçu'nun, özellikle, demokrasinin esaslarından olan eşitlik düşüncesini, geliştirdiği madde-ruh merkezli perspektif etrafında değerlendirdiği görülmektedir. İnsanların, varoluşsal veçhelerini oluşturan madde ve ruh açısından, eşit olup olmadıklarını sorarak verdiği cevaplarla tercih ettiği ekonomi-politik sistemin ipuçlarını vermektedir. "Madde olarak bütün insanlar arasında nispi bir eşitlik bulunduğuna" inanan Topçu (2014a, s.138), maddi plandaki eşitliğin iktisadi alanda eşitliğe dayanan sosyalizmi ilzam etiğini düşünmektedir (İşler, 2019, s.148-154). "Ruh bakımından ise, her birimizin kendinden üstün ruhu arayarak hürmetle ona çeorilmesi" (Topçu, 2014a, s.138) gerektiğini ileri sürmekte ve ruhlar arasında eşitlik olmadığını beyan etmektedir. Ona göre, insanlar madden eşit olsa da, ruhen farklı yaratılmış oldukları için demokrasinin eşitlik iddiası, ruhlar arasındaki derece farkını yok saymakla maluldür.

Demokrasinin eşitlik ve özgürlük düşüncesinin halk nazarında olumsuz neticelere yol açtı̆̆ına dikkat çeken Topçu (2014a, s.138), insanların kendilerini ahlaken ve ruhen eşit gördükleri bir dünyada hürmet ve itaat düşüncesinin zayıflayacağını iddia etmektedir.

"Demokrasi insanın büyük ve ilahi tarafin budayarak onun hirsları ve menfaat emellerine hayat kazandirıyor" (Topçu, 2014a, s.137) diyerek demokratik sis- 
temlerin insanın maddi/bedeni/şehevi/nefsani tarafını kışkırttı̆ını savunmaktadır (Kara, 2016, s.51). "Ilim sanat ahlak ve din gibi insan ruhunun ideal atılışlarmm Allah'a doğru ilerleyişi demokraside yön değiştirerek halkın hırslarma çeoriliyor" diyen Topçu (2014a, s.137), herkesin eşitlik vehmine kapıldığı bir ortamda, yüksek ideallerin yerini maddi ihtiraslara bıraktığını düşünmektedir.

Bu bağlamda Topçu (2014a, s.133-134), demokrasinin eşitlik idealinin gerçekçi olmadığını aksine çoğunluğun içerisinde bilhassa belirli kesimin çıkarlarına dayanan bir rejim olduğunu vurgular. Bu yönüyle yöntem olarak Marksist bir yaklaşım mevzunun izah edildiğini ancak içerik açısından farklılık arz ettiğini belirtmek gerekir. Marksizm'in demokrasinin eşitlik eleştirisi, üretim araçlarını kullanan işçilere karşı üretim araçlarını elinde bulunduranların çlkarlarını koruyacak sınıf temellidir. Fakat Topçu, Marksizm'in sınıf temelli yaklaşımdan farklı olarak demokrasi rejiminin temel düsturlarından eşitliği, emek işçisi ve patron olarak değil halk ve sermaye dikotomisi şeklinde ele alarak eleştirir. Yani Topçu (2008, s.38), demokrasi rejiminin ideal olarak sunduğu eşitlik iddiasının aksine "patron-amele sintflaşmasımı değil... Sermaye sımıfı ve halk sımıfı" ikililiğini doğurduğunu belirtir.

Demokrasi, sosyal sözleşme ile toplumun tüm kesiminin katılımının sağlandığı yönetim rejimi özelliğiyle eşitlik sağladığını ortaya koymaya çalıssa da Topçu (2008, s.94), demokrasi için "fertler fertlerle değil fertler müesseseler ile mukaveleye girişmektedirler ve fert her zaman müesseseden zayıf olacağına göre, müessesenin ferde zulmü pek kolay olacaktır" şeklinde yapmış olduğu izah ile yapılan sözleşmenin taraflarının aynı güç ve imkânlara sahip olmadığını göstermeye çalışmıştır. Haliyle demokrasi, gücün eşit bir şekilde dağılımını sağlayarak bir yönetim biçimi değil daha ziyade gücün belirli bir zümrenin elinde toplanan ve kurumsal bir nitelik kazanan rejim olduğunu Topçu (2014a, s.134) şöyle serdeder:

"Demokrasinin sunduğu hürriyet hiçbir zaman ruhî ve ahlâki hürriyet mânasını kazanmadı... Demokraside halkın hâkimiyeti fikri bir paroladır. Gerçekte hâkimiyet, halkm bütünlüğ̈̈nde değil, halk içinde türeme firsatın bir sürü kuvvet zümrelerinin elindedir. Demokrasi de monarşi gibi kuvvet rejimidir; hak rejimi değildir. Ancak tek kuvvet yerine çoğalan ve dağılan kuvvetlerin rejimidir. Halk, her taraftan kendini çeviren bir kuvvet gruplarmın esiri olmaktadır. Sermaye esareti bunlarm en ezici olanıdır." 
Bu ifadelerini destekler nitelikte Topçu (2017, s.233-234), demokrasinin, belirli bir sınıfın yani sermayedarların çıkarlarını koruyan, tahkimini sağlayan müesseselerden oluştuğunu ve halkın bu müesseselerle tahakküm altına alındığını, zorbalığa maruz bırakıldığını belirterek devlet mekanizması ile halkın, "eşitlik" düsturu içerisinde değerlendirilmesinin imkânsızlığına vurgu yapar. Çünkü yazara göre, devlet, halka nazaran daha büyük bir teknik üstünlüğe sahiptir. Devlet ile halk aynı olanaklara sahip değildir. Dolayısıyla Topçu (2008, s.93), "taraflardan birinin zorlamasıla yapılan veyahut bir tarafin üstün kuvvetiyle tatbik edilen mukavele hakikatte varsayllabilir mi? Elbette sayılmaz" diyerek demokrasinin eşitlik ilkesinin gerçekleşmesinin mümkün olmadığını belirtir.

Öte yandan demokrasinin sunduğu "özgürlük" umdesini Topçu (2008, s.46-47) "eski çürümüs nizam içinde, dışı hürriyet teraneleri ile parlayan, lakin iç yüzü her ferdin kendi insiyaklarmnn en üste yükseltilmesini ve onlarm tahakkümü arzusundan ibaret hale getirilen demokrasi, bazen umumi iradenin katili olabilir. Herkes kendi iradesini istiyor ve hepsinin iradesi birbiri ile çarpışıyor." şeklinde ele alarak özgürlüğün bireyin sahip olduğu ihtiras, hurs, güç gibi bir başkası üzerinde egemenlik sağlamaya çalışacak içgüdülerin ortaya çıkmasına ve/veya tetiklenmesine neden olacağını, bunun ise toplumsal iradesinin sonuna neden olacağını vurgular.

Demokrasinin bireye sunduğu hürriyet idealinin toplumsal iradenin tahribatına sebep olduğunu vurgulayan Topçu (2014a, s.152-54), gerçek hürriyetin "fertlerin hürriyet adı altındaki serbest davranışları selametin yolu değildir. Bu hal olsa olsa oylama ve esaret içinde avunma hezeyanını yaşatıcıdır. Demokraside her vatandaşın kendi ferdi iktidarmı serbestçe hareket haline getirebilmesi, diğer vatandaşlarm hürriyetine zincir vuruyor. Ferdi hürriyetlerin çoğalttı̆̆ı zincir halkaları bütün vatandaşlar için gittikçe ağırlaşan bir esaret zinciri halini almaktadır" diyerek bireye ve farklılığa dayalı değil "iradenin aileyi cemiyeti ve devleti istemesi onun kendi kuvvetini denemesidir. Bunlar istemeyen, bu gerçeklere doğru hamle yapamayan irade kendi içinde yaşattığı boşlukta bunalmaya mahkûmdur" diyerek birliğe ve ahlaka dayalı olması gerektiğini salık verir. Topçu (2014a, s.151) bunun "içten veya dıştan iradeye yabana hiçbir kuvvet tarafindan zorlanmaksızin bizzat kendi seçimi ile kendi kendisini belli bir harekete zorlanmak hususunda iradenin sahibi olduğu kudret (olan) ahlaki hürriyet" olduğunu belirtir. Hürriyetin ahlaki ilkelerini belirleyen iradedir. "İnsan iradesinin içten gayesi... Ahlaki düzenini gerçekleştirmek... Asıl gayesi olan Allah'ı aramaktır. Bu sebepten 
din, bütün samimi ve hür hareketlerimizin gerçek gayesidir. Insan en büyük hürriyetini Allah'ı arayışında hisseder" diyen Topçu (2014a, s.152) topluma bu iradeyi verecek olanın ise dinden aldığı motivasyonla-dinden beslenerek ahlaki değerlerini ve kişiliğini bir araya getiren elit bir kesim olduğunu vurgular.

\section{Seçim - Oy - Temsil}

Topçu'ya (2014a, s.125) göre "Demokrasi kendinden beklenen gayeye ulaşabilmek için onu kullanan insanlardan kemal ve fazilet ister monarşide bir fert veya zümrenin fazileti yeterliyken demokrasinin selameti için idareye iştirak eden her ferdin hatta oy kullandiklarn için bütün halkm faziletli olması gerekir." Ancak toplum "içerisinde her zaman bulunan cahillerle menfaatçilerin sayısı olgun ve faziletli insanlardan daha çok olduğundan" ortak erdemli bir tutumda bulunulmasinın imkânsızlığını göz önünde bulunduran yazar "genel menfaat fikir ve idealine sahip olmayıp da seçmenlerin arzularına söz vermek suretiyle seçilenlerin kuracağ demokrasinin tam manasıyla demogoji" (Topçu, 2014a, s.130) olduğunu ortaya koyar. Topçu (2014a, s.130), halkın cemiyetin selamet şartı olan genel menfaat fikir ve iradesine sahip olamayacağını çünkü ferdi ve özel menfaatlerin buna engel olduğunu vurgular. Yazara göre zaten genel iradenin gerçekleşmesini sağlayan bir mekanizma olarak "seçim, millet fertleri arasinda değil ihtirash kurnaz angaje adamlar arasinda cereyan eder... Halkm ben idare ediyorum demesi (bile) safsatadır" (Topçu, 2014a, s.132).

Ulvi yetkinliğe ulaşmış seçkin azınlığa kuvvetli irade bu aşamaya gelemeyen halkın çoğunluğunu oluşturanlara ise zayıf irade tanımlaması yapan Topçu (1997, s.83), "kuvvetli iradeler doğurur zayıf iradeler taklit eder" diyerek elit bir kesimin iradesinin devlet idaresinde teşekkül edilmesi gerektiğini belirtir. Fakat yazara göre demokrasi, "bilenle bilmeyeni bir tutarak" (Topçu, 2014a, s.125) kuvvetli iradeye sahip olanları zayıf iradenin seviyesine indirmektedir.

"(Demokrasi rejiminde) her vatandaş aynı oy hakkına sahiptir. Bu hususta cahille âlimin, filozofla amelenin, şerir ile velinin farkı tanınmıyor. Hayatımın kemal mevsimine ulaşmış olgun ve faziletli bir hâkim ile psikopat bir katil yan yana oy kullanıyorlar. Her ikisinin oyları tatbikatta aynı değeri taşıyor."

Öğün'ün (1991, s.120) dediği gibi amaç kitleleri yukarıya çekmek olmalyyken demokraside tam tersi olmakta üstün seviye ve kültür sahipleri hal- 
kın hizasına indirmekte onların iradesini halkın emrine vermektedir. Bu noktada Topçu (2014a, s.146), "halkın iradesi, daima çoğunluğu teşkil eden aşă̆r tabakanın iradesidir; düşüncelerin değil, cahilin ve ayak takımının dilekleridir; âlimle filozofun değil, düşünmeyenlerin çok ve çeşitli duygularla karışık, uzağı görmeyen, telkin ve taklit mahsulü heveslerinin karmaşığıdır. Onda yakm ve mahdut fayda unsurlarıyla kin, hased ve zümre gururları karışıktır. O saf bir irade olmadı̆̆ gibi yüksel bir dilek de değildir" diyerek kuvvetli irade ile zayıf irade arasındaki farkı netleştirir. Tüm bu gerekçelere dayanarak Topçu (2014a, s.146-147), demokrasinin oy umdesinin genel iyiliğin yerine ferdi menfaatleri ön plana çıkaracağını ve genel menfaati amaçlasa bile bunu yapabilecek, doğru ve yanlışa karar verebilecek donanımdan mahrum olduğunu şöyle vurgular:

"Halkın iradesi, umumi menfaati tam olarak içine almadığı gibi istikbali de ihata edemez. Halk, kendi hayır ve şerrini çok kere iyi bilmez. Ruh ve madde farkını ölçemez. Teraziye koyduğu zaman, ufak bir maddi nimet büyük bir ruh eserine çok kere üstün görür. Halk kendini büyük bir ruh eserine çok kere üstün görür. Halk kendini şaşırtan ve perde arkalarmdan idare eden sinsi kuvvetleri de göremez. Halkn cehaleti en büyük düşmanı iken, bu cehlini hayatına hâkim kılmak kendi kendisine zulüm değildir de nedir?"

Topçu (2014a, s.125-131), demokrasi rejiminde olgunluğa erişememiş olan halkın "en fena emeller elinde oyuncak olmasının her zaman mümkün" olduğunu belirterek şuursuz halk kitlesinin kendisini temsil eden, temsil edenlerin hamileri ve onların sahip oldukları araçlarla aldatılarak, yönlendirildiğini şöyle aktarır:

"Halk kütlesi yüzünü, kendini irşad eden kimselere çevirmiştir. Halk sade kendi akliyle oy kullanmaz. Gazeteler, partiler ve bütün münevverler, halka doğru yolu gösterirler. Ancak bunlarn da halkı aldattıkları ve kendi menfaatleri uğruna halkı doğru yoldan uzaklaştırdıkları çok kere görülen şeydir... (Onların) menfaatleri milli menfaatleri çok geride bırakır... Halk oyunu idare ederek ona istikamet veren basın sermaye sahiplerinin emrinde çalışan şahsi menfaat grubudur... Halk oyunun kullanilmasında rol oynayan diğer unsur ise seçimleri idare edenlerdir. Adayliklar, yoklamalar, propagandalar bazen halk oyunun safiyetini ortadan kaldirarak onunla oynarlar, onu yok edesiye örseler, mahiyetini değiştirirler."

Böylece seçmen denilen büyük halk kitlesinin hiçbir endişeye mahal vermeden içlerinden geldiği gibi temsilcilerini seçtiklerini iddia etmek oldukça zordur. Topçu'nun (2014a, s.128) dediği gibi "hiçbir yönetici prensibin haki olmadığı seçim, zar atmaktan veya piyangodan farksız olacaktır." Seçmen ve 
seçilen arasında böylesi bir ilişkiyi ortaya çıkaran demokrasi rejimi, "tam manastyla demogoji haline gelmeye mahkûmdur" diyen Topçu (2014a, s.130) göre, bu yönetimde temsil eden ile temsil edilenler, temsil edilen kesim ve temsilciler arasında yer yer aykırı istekler çarpışır, menfaat cepheleri ayrılır, her cephe bir partiyi meydana çlkartır. Bunlar da birbirleriyle bir nevi düşman savaşına girerler. Haliyle demokrasi, düşmanlık fikriyle birleşir, fikirlerin çarpışması yerini menfaatlerin çarpışmasına bırakır.

\section{Halkın/Çoğunluğun Yönetimi}

Belli bir sözleşme neticesi sonucunda kurumsal çerçevede bir araya gelen topluluğa "cemiyet" yakıştırması yapan Topçu (2017, s.235-236) göre, bu kavram; ruhun yerine maddi olanı tercih eden, doğal olmayan yalnızca kendi çıkarlarına dayalı anlayıştan kaynaklı olarak ahlaktan yoksun niteliklere sahiptir.

"Cemiyetin ahlâkı olmaz. Ĕğer bu ahlâklarm gayesi bir cemiyetin selameti ve menfaati kaygısı ise bu ahlâk, cemiyet denen varluğın kendi işine kapalı bencil haklarının korunması için yapılan teşkilâttan başka bir şey değildir... Cemiyet menfaati değer yaratamaz.... Cemiyetçilik, esirliği doğurur."

Bunların yanı sıra Topçu (2016, s.110-111), cemiyeti bilinçsiz bir yığın olduğunu tarihsel kişilikler üzerinden izah etmeye çalışmıştır.

“Sardanapal'ler, Sezarlar, İskenderler ve Napolyonlar... Bu zalimlerin zulmünden yapılmış zafer abidelerini tarih boyunca yücelten insanlık, kendi ruhunun kurtarıclarma vatan haini demekten hiçbir zaman utanç duymadı. İskender'i ilahlar arasina yükseltecek cemiyet, daha önce Sokrat'a vatan haini demişti. Nice vatan hainleri ile varlı̆̆ târümâr edilen cemiyetimiz vatanindan ayrıldığ için, Mehmet Âkif'i lekelemeye çalışanlar da gördü."

Böylesi bir perspektifle mevzuya yaklaşan yazara göre, çoğunluğun iradesi, bireysel iradenin düşmanıdır. Hatta çoğunluğun iradesinden de bahsetmek mümkün değildir. İrade denilen şey bireyseldir (Topçu, 2014a, s.52; 1948: s.2). Bunu gerekçe olarak gösteren Topçu (2017, s.171), Gökalp'ın "fert yok cemiyet var" yaklaşımına sert eleştiriler getirir. Gökalp'ın, milletin ruhunu felce uğrattığını, büyük insanların tamamının fert olduklarını gözden kaçırdığını belirtmiştir. İstitrat kabilinde Topçu (2016, s.50), salt fertçi bir tasavvur içerisinde de değildir. Tasavvufun ahlaki ve felsefi değerleriyle 
beslenmiş, biçimlenmiş fertlerden oluşan ahlaki cemaat tahayyülü içerisindedir. Keza fert dahi bu cemaat içerisinde sınırlandırılmıştır.

"Cemaat, üstün olan bir ideale ferdiyetlerini feda ederek birleşen insanlar topluluğuna denir. Durkheim, cemaate bağllĭğın başladığı yerde ahlakın başladığını söylüyor. Ahlaki bir cemaat, hem ferde hem cemiyete üstün olan sonsuzlukta karar kılan bir ideale kendini iradeyle teslim eden topluluktur. Yine aşkm getirdiği teslimiyet duygusu, bizi cemaatin içerisinde eritir."

Bir başka ifadeyle Topçu'ya (2017, s.39) göre; Durkheim, "ferdin şuuru yerine cemiyetin şuurunu, ferdin vicdan yerine cemiyetin vicdanını, ferdin Allah'ı yerine cemiyetin ta kendisini" koyarak aşırı cemiyetçilerin alemdarlığını üstlenmiştir. Bu görüsse göre, ferdin cemiyetten bağımsız bir şuura, vicdana ve inanca sahip olması mümkün değildir (Şen, 2016, s.57). "Fert, cemiyetin her taraftan kendini çeviren tazyik cihazı içerisine sıkışııs bir otomattan" (Topçu, 2017, s.39) ibarettir. Topçu, bizde Durkheim ekolünün mümessili olarak Ziya Gökalp sosyolojisini görür (Aydoğdu, 2009, s.452). Göklap'ın “fert yok cemiyet vardır" mottosunu, Durkhemci -aşırı cemiyetçi- telakkinin türevi olarak değerlendirir. Gökalp' in cemiyet karşısında ferdi yok sayan görüşlerini "feragat ahlakı çıartacak yerde ferdi şahsiyeti inkâr ettiren" (Topçu, 2017, s.40) yaklaşımlar olarak değerlendirir. Böylece Durkheim-Gökalp örnekleri üzerinden aşırı cemiyetçi görüşler olarak isimlendirdiği ekolü, "ferdin hataya ve şerre isyan edici ruhunu" (Topçu, 2017, s.40) yok saymakla itham eder. Topçu'nun ele aldığı ikinci yaklaşım tarzı ise, aşırı ferdiyetçilik olarak tanımladığı ekoldür. Rousseau ve Nietzsche isimleri üzerinden bu ekolün ana hatlarını sunmaya çalışır. "Rousseau'ya göre insan, cemiyet hayatına girdiği günden beri gerçek benliğini teşkil eden kalbini kaybetmiştir. Şimdi her yerde insanin durumu sefalettir. Çünkü her yerde insan cemiyet içindedir. Onun için tek kurtuluş çaresi cemiyeti terk edip tabiata dönmektir" diyen Topçu (2017, s.42); Nietzsche'nin ise, "sürü dediği cemiyetin içindeki insanüstü varliklarn (übermensch) ayırarak ahlakı ve bütün idealleri bunlara bağışladığını" (Topçu, 2017, s.42) ileri sürmektedir. Topçu'ya (2017, s.42) göre bu düşünürler, cemiyetin ferdi küçülttüğüne inanırlar. Onlara göre, ahlaki varlığa sahip olabilecek yegâne unsur ferdin bizatihi kendisidir. Cemiyetin bir şahsiyet olarak varlı̆̆ından dahi söz etmek mümkün değildir.

Aşırı cemiyetçi ve ferdiyetçi görüşleri özetledikten sonra iki yaklaşım tarzını da insanlık için hayra alamet bir durum olarak görmeyen (Birgül, 2016, s.72) Topçu (2017, s.42), "şimdi aşırı cemiyetçilik ile aşır ferdiyetçilik a- 
rasında hangi durumu seçeceğiz? İkisini uzlaştırma denemesi mi yapalım?" diye sorar ve "biz bu iki doktrini ruhu sakatlayacak olan uzlaşttrma denemesine başvurmayacağız" diyerek fert ve cemiyete ilişkin kendi yorumlarını paylaşır. Cemiyeti; "gördüğümüz karakterlere sahip olaylarıla ferdi her tarafindan ihata eden çevre" (Topçu, 2014b, s.19) şeklinde tanımlarken, ferdi; "maddeden zaman zaman, bazen de süreli olarak iradesini styırabilen ve egoizme minnettar yaşamayan" (Topçu, 2017, s.50) şahsiyet timsalleri olarak görür. Ona göre peygamberler, veliler, sanatkârlar gibi cemiyet üstü şahıslar maddenin ruh üzerindeki baskısını kırabilen fertlerdir (Topçu, 2017, s.51).

Öğün'ün (1991, s.60) vurguladığ1 gibi Topçu'nun, düşünceleri her ne kadar genel irade karşısında ferdi iradeyi yüceltiyor gibi görünse de aslında savunduğu şey yine topluluktur. Bireysel kurtuluşu tek başına bir başarı olarak görmez. Kurtulan aynı zamanda, kurtarma misyonunu da gerçekleştirmek zorundadır.

Cemaat içerisinde ferdiyetçiliğin savuculuğunu yapan Topçu, genel irade kavramının yok hükmünde kabul ederek cemiyeti olumsuzlayarak çoğunluğun yönetimini sorunlu bir durum olduğunu ortaya koymaya çalışır. Topçu, halkın çoğunun ruhen ve ahlaken aşağı seviyede insanlardan oluştuğunu iddia etmekte ve çoğunluğun egemenliğini bu bağlamda eleştirmektedir: "Her yerde cahili âlimden, şahsi menfaat düşkünü faziletlisinden, nefsine düşkünleri hizmet ehlinden kat kat fazla sayıda bulunan halk, toplum düzenini en iyi şekilde idare etmeye istidath değildir" (Topçu, 2014a, s.133). "Bu rejimde bilenle bilmeyen bir olmaktadır her vatandaş ayn oy hakkna sahiptir; bu hususta, cahille âlimin, filozofla amelenin, şerir ile velinin farkı kalmıyor; faziletli bir âlimle psikopat bir katil yan yana oy kullanıyor" diyen Topçu (2014a, s.125), "cemiyet içinde her zaman cahillerle menfaatçilerin sayısı olgun ve faziletli insanlardan daha çok olduğundan sayıları sebebiyle bu rejimde onlar ağır basacak ve cemiyeti hep kötüler idare edecektir" (Topçu, 2014a, s.125) sözleriyle demokrasiyi, keyfiyete (niteliğe) karşın kemiyeti (niceliği) öne çıkaran bir sistem olması sebebiyle eleştirmektedir.

Demokrasinin diğer sacayaklarını da aynı minvalde (madde-ruh ekseninde) kritik eden Topçu (2014a, s.130), "ortak çkar" kavramının gerçekliğinin şüpheli olduğunu çünkü halkın, cemiyetin selametinden önce kendi menfaatini düşündüğünü ve kendi menfaatinin de çoğunlukla, daha iyi bir ev/araba/iş/prestij gibi maddi/nefsani amaçlara yönelik olduğunu iddia etmektedir. "Genel irade" kavramının da benzer şekilde, bir çeşit il- 
lüzyon olduğunu ima eden yazar, basın ve sermayenin propagandalarıly halkın iradesinin belirli menfaat grupları lehine manipüle edildiğini (Topçu, 2014a, s.131) düşünmekte, bununla birlikte, "gerçekte egemenlik halkn bütünlüğünde değil; halk içinde türeme firsatı bulan bir sürü kuvvet zümrelerinde" (Topçu, 2014a, s.134) sözleriyle, genel irade kavramının da gerçekliğe isabetinin şüpheli olduğunu izhar etmektedir.

\section{Topçu'da İdeal Yönetim Biçimi: Demokrasi Yerine İrade Rejimi}

Topçu (2008, s.23-24), "bütün kâinatın gerçek sahip ve mesulü bir olan Allah'tır. Devlet idaresi de onunla bizim aramızda birlik halinde gözüken bir irtibat iradesidir. Devleti Allah'a en uzak mintıkalarda çoklukta dağıtarak yok eden madde olduğu gibi onu Allah'a en yakm mintıkada birlik yapanda ruhtur. Böyle bir ruha herhangi bir şekilde sahip bulunmayan bir demokrasi oy, el, ses çokluğu, sayı madde belki de ikna saltanatlarn kurar birlikten çokluğa inince, ruhtan maddeye, mesuliyetten mesuliyetsizliğe geçilir. En kalabalık meclislerde kukla oynatılır ve meddahlik yapılır. Çokluktan birliğe doğru yükselince âlem-şümûl mesuliyetle çarpan kalpler Allah'a yaklaşır ve orada Ene'l-hak sırını çözmeğe bir vasıta olurlar." diyerek kaynağını pozitivizmden alan, halka dayanan çoğunluk yönetiminin yerine maneviyatı yüksek mertebede tutacak mutasavvıf bir iradeyle ruh birliğine dayanan rejimin savunusunu yapar. Bu rejim Topçu'nun "milli devlet"ine tekabül eder. Keza Topçu'ya (2014a: 120-121) göre bir tür kura sistemi gibi çalışan, halkın iradesinin yansıtıldığı yalanıyla üretilmiş olan demokrasilerde milli devletin ne olduğu anlaşılamıyor. Yani çoğunluğun iradesiyle örselene örselene cansız bırakılan toplumun kurtuluşu milli devlettedir. Milli devlet, millet için çalışırken demokrasinin neticesi olan şahsi menfaat arzuların köstekleyen devlettir. Milli devlet, dinini ve dilini kutsal kurumlar halinde koruyabilen devlettir.

Diğer bir ifadeyle Topçu (2008, s.21), halkın kontrolüne dayanan yönetim kaynağında ihtiraslar barındırdığını bunun ise toplumun yıkımına neden olacağı bu gerekçeyle kurtuluşu yalnızca Allah'a dayanan, gücünü ve iradesini ondan alan rejimin muvaffakiyete ulaşacağı iddiasındadır.

"Millet mesuliyetini Allah emriyle üzerine alan insandır. Vicdandan fişkırtp ele ve dile gelen bu emir, eğer ilahi bir kaynaktan gelmese insan, bu kadar ezici bir mesuliyeti, bir milletin mesuliyetini üzerine alamaz. Bazen bu mesuliyetin, Allahsızca 
da yüklenildiği vardır. Ancak bu halde sebep, muvaffakiyet ihtirasıdır. Yürüyüş Allahsız olunca ihtiraslar bir gün mutlaka devlet gemisini uçuruma götürür."

Ögün'ün (1991, s.118) dediği gibi Topçu'nun düşünceleri çerçevesinde din ve devlet ilişkisinde; din, devlet dışı ama o oranda devlet üstü bir konumda tutulmaktadır. Ahlâk sistemi olarak din, devleti topluma karşı ılımlaştıran ve adil bir düzenin kurulmasında ona yol gösterendir. Devlet adamları, din seçkinlerinin irşadından yola çıarak devleti yönlendirmelidir. Laik düzende olduğu gibi din ve devlet ayrı alanlarda düzenlenmemelidir. Daha ziyade din ve devlet ayrımı yatay değil dikey olarak gerçekleştirilmelidir. Bu bağlamda din, devlete nazaran yukarıda olmalıdır. Ahlaklı ve adil bir toplu inşası için dinin dogmalarına göre devlet ve politikaları biçimlendirilmelidir.

Böylece demokrasiyi eleştirel şekilde ele alan Topçu, onun karşısına ruhçu-idealist bir seçenek koymaktadır. "Insan şahsiyetini derinden sarsan ağırlı̆̆ ortadan kaldıracak tek çare ruhi ve ahlaki bir otoriteye teslim olmaktır" diyen Topçu (2014a, s.149), madde cephesinin zaferi olarak telakki ettiği demokrasinin karşısına ruhun selametini sağlayacağını düşündüğü ideal rejimi koymaktadır (Topçu, 2014a, s.144):

"Demokrasi keyfiyetin yerine kemiyeti koyduğu gibi ruhun yerini de maddeye bağış̧lıyor çoğunluğun sözünün geçerliliği kemiyetin hâkimiyetidir. Bir toplumun ferdi ruhtaki akislerinin yerine toplumun madde olan kütlesinin hâkim oluşu ise ruhun yerine maddenin geçirilmesidir. Toplum içinde her ferdin dileklerini hâkim kılmak gaye olmamalıdır; çünkü toplum hayatında en bayağısından başlayarak iyi ve kötü bütün dilekler yaşatılmaktadır. Bunlarm kültür ve ahlak bakımmndan yükselmiş fertlerin ruhlarmdaki akislerinin bizzat bu büyük ruhlar tarafindan seçildikten, elendikten, ayıklandiktan sonra temiz ve Allah'a yararl olanlarınn ayrilip cemiyette kuvvet haline getirilmesi ideali teşkil eder. (...) Batı medeniyetinin ortaya koyduğu sayısız değerlerin yıkılışı demokrasinin inkişaf devrine rastlamış bulunuyor; bunu bir tesadüf diye karşllamak safdillik olur. Kura ve kader rejimini ideal rejim diye benimsemek devrin ilim düşünüşü ile de çelişmektedir. Bizce en iyi rejim irade rejimi olacaktır."

Topçu tahayyül ettiği ideal rejimin idaresinin, seçkinler/elitler tarafından yürütülmesi gerektiğini vurgular. Bahsini ettiği yöneticilerin ise ne tür vasıflara sahip olduğunu tartışmaya çalışır. Bu noktada Topçu (2016, s.57-58), seçkinlerden oluşan yönetici sınıfın niteliğini gerçek bilgiye sahip olma/ulaşma hususunda serdettiği fikirlerinden yola çıkarak izah eder. Ona 
göre, gerçek bilgi metafizik bilgidir. Dolayısıyla -Bergson'dan (Topçu, 2011) yola çıarak- mistizmi bertaraf eden pozitivizmin ulaştığı bilgi, akılla izah edilemeyecek ölçüde içi boş, cansız ve ruhsuzdur:

"Metafizik, aklnn kainata açılması, onu bütün halinde kavrayış cehdidir. Kâinat hâdiselerini ilimlerin çizdiği hudutlar içerisinde ayrı ayr gruplara ayırı, her ilme mahsus olan ayrı metodlarla başka başka yollardan giderek onu tanımak istediğimiz zaman kâinatımı bölünüyor; bütünün karakterlerini bölümlerde bulmak kabil olmuyor. Kâinatm oluşundaki hayat ve bütününde bulunan ruh ortadan kalkmast, aklın iflası olur. Metafiziksiz yaşamak aklı ortadan kaldırı yalnı duygularla yaşamaya razı olmaktır."

Topçu, ruhun karşısında maddeyi öteleyen böylesi bir yaklaşımla "bilgìye ulaşan insan, bilgilerin bilgisine ulaşmıştır. Nesnelerin dünyasında bocalayan, dağılan varlığını önemsemez çünkü bilmektedir ki, beden bir cesarettir, aslolan ve ona sonsuzluğun kapıların açacak olan güçler ruhunda saklıdır." (Akt. Öğün, 1991, s.47) diyerek gerçek bilgiye nasıl ulaşılması gerektiği noktasında fikir beyan eder. Ruhunda saklı olan, ilahi ve mistik bir güçtür. Yani ilahi irade ile iştirak halinde bulunan insan hür bir irade sergilemiş olur (Topçu, 2016, s.149). Hürriyet ise, üst bir irade olan Allah'ın iradesiyle sınırlandırılmıştır. İşte bu bilgiye sahip olan insan hareket adamıdır (Topçu, 2016, s.141-142).

"Hareket adamı, bazen vatanperver olur, bazen âlim, bazen sanatkârdır. Bazı kere devlet adamı vaziyetinde görülür. Her zaman ahlak adamıdır. Her zaman kâmil insandir... Hareket adami, her yerde nizam yapıcıdır... dinde, sanatta, ilimde hatta inzivada görülür ve en kuvvetli inzivasında kendine ve âleme hayat olandır. Hareket adamın bin bir ifade ile bin bir çehresiyle size takdim etmek kabildir. Ancak onun kim olduğunu söyleyelim. O, meş'ûm yalnzzliktan kurtulmuş Allah'l adamdır. Durmadan Allah diyen sofì değil, iradesini Allah'la birleştirmiş, onunkini kendisininkini yapmış bahtiyar adamdır."

Topçu (2014a, s.16), serdetmiş olduğu fikirlerinden devlet idaresini elinde tutacak olanların ne tür iradeye sahip olması gerektiği hususunda yine kendi cümleleriyle çıkarım yapmak mümkündür.

“Gayesine ulaşlabilen gerçek ve tam irade... Allah'a ulaştıran iradedir. Damarlarımizdan sizan iradeyi, kendi eserimiz zannetmekle yanllyoruz. Hakikatte irade birdir. $O$ istek halinde âleme yaygin kudretin bizdeki adidır. Aslinda bu eorensel iradeye biz sadece iştiyak halinde yaşıyoruz. İslam dünyasının külli irade-cüz'i irade ayrımı sun'idir. Benliğimizde barnnan iradeyi âlemin iradesinden, daha şahsi ve tam 
adı ile Allah'ın iradesinden ayırı onunkine denk bir kudret gibi düşünmek zavall insanlığımızın aczinden fişkıran bir kibirden başka bir şey değildir."

Topçu'ya (2014a, s.21; 1947: s.3-5) göre, ortaya konulması gereken irade, tasavvufi açıdan dış dünyaya karşı içsel bir kuvvettir. Diğer bir ifadeyle yazar, devlet erkânının tasavvufun kalp eğitiminden geçerek (Topçu, 1997, s.156-157), felsefesinden beslenerek (Topçu, 2017, s.57-58), İslam ahlakının özüne ulaşarak hem ruhen hem de ahlaken yükselmeleri gerektiği noktasındaki tasavvuruyla bir ölçüde devlet idaresini elinde bulunduranların nasıl olması gerektiği hususunda reçete sunar.

Topçu (2017, s.206-208), pozitivist siyaset adamını; zekâsı kalp için hareket etmeyen, maddeyi ruha tercih eden, kendi çıkarları için toplumu kullanan, ikna edici, aldatıcı kabiliyetlere sahip biri olarak tanımlar:

"Başkalarını kendi yaşayışı (için) kullanan (bu yol) kalbe düşman zekânın yoludur. Kalbi varliğına inanmayan ve zekânın desise ve hile âleti, gizli bir hançerli el olduğunu anlayıp dünyaya küskün yaşayanlardır... (bunlar) zekânın kalp için vasıta olmadı̆̆ı (kişilerdir)... Aldatmak, idare etmek, yolunca gitmek, kullanmak kalp tazeleğinin çürümüş oldŭ̆unu ilan eden bu kelimeler kaybolmuş zekânın esiridir. (pozitivist siyaset adamı), âlicenaplık(la), çok kelime ile güzel kelime ile konuşan, kolaylıkla ve halk içinde bollukla iyilik yapar... Kendi dişındaki değerlerle yaşayan (bu) adam ahlâklı olamaz."

Topçu'nun ahlâklı olmayan pozitivist siyaset adamı yaklaşımı, esasen ahlâklı devlet idarecinin nasıl olması gerektiğinin ipuçlarını verir. Bu hususta Topçu (2017, s.208), "ahlâk örneğini, iyi adam değer kalp adamı verebilecektir" diyerek siyasetin içgüdüsel bir duygu olduğunu bu minvalde yola çıkarak da siyaset adamının en önemli niteliğinin maddeden ruha yükselmesi olduğunun altını çizer. Yazar, nasıl ki "talebesi, irfan ve ahlak yolundan sapan muallim muzdarip (olur)" (Topçu, 2017, s.212) derken aslında nefisini, ruhunu ulvi değerlerle beslenmeyen bir idarecinin de muzdarip olacağının işaretini verir.

"İdare bir sanat olduğuna göre halkın gerçekten ve azimli olarak kendi kendisini idare edeceğini, idare işinin bir ihtisas işi olmadığını düşünmek hatalı olur" diyen Topçu (2014a, s.133) "ihtisas" kelimesi ile devlet idaresinin bir yönüyle kaynağın dinden alarak "hissetme, duyma, duygulanma" (Develioğlu, 2015, s.483) ile ilişkili olduğunu diğer yönüyle "bir ilim veyâ san'at üzerinde fazla çalışarak onda derinleşmiş olma" (Develioğlu, 2015, s.483) durumunu ifade eden uzmanlık ile ilgili durum olduğunun altını çizer. Yani yöneticinin dinden 
beslenerek ruhunu terbiye edip, ahlakını şekillendirip devlet idaresine dair ilmi açıdan uzmanlaşması gerektiğini belirtir. Bu yüzden Topçu (2014a, s.133) "bütün halkın kendini idare etme işini omuzlarna yüklenmesi demek olan demokrasi (için) geçici bir rejimdir" der.

\section{Sonuç}

Muhafazakârlık modernite ile birlikte baş gösteren köklü değişimlere karşı geleneksel değerlerin muhafazasını amaçlayan bir tür ideoloji olarak ele alınmaktadır. Tarihsel süreklilik sağlayacak değer ve normlara yapılan vurgu bu ideolojinin ana hatlarını oluşturmaktadır. Avrupa'da her ne kadar Anglo-Sakson ve Kıta Avrupası gelenekleri arasında muhafazakârlığın içeriği açısından farklılık söz konusu olsa da, her iki yorumlama biçimini de muhafazakâr düşünce olarak ele almamızı mümkün kılacak ortaklıklar söz konusudur. İnsanın doğasına yönelik kötümser yaklaşım, çoğunluğun vermiş olduğu kararlara şüphe, aile başta olmak üzere toplumsal ilişkileri yeniden üretecek müesseselerin önemine vurgu, genel irade, ortak çıkar, hürriyet ve eşitlik gibi Fransız devriminin bayraklaştırdığ 1 kıymetlere mesafe ya da bu kıymetleri yeniden tanımlama gibi değerlendirmelerin muhafazakâr ideolojinin ana çizgilerini oluşturduğu söylenebilir.

Nurettin Topçu da bir muhafazakar düşünür olarak benzer temalara eleştiriler getirmiş, gelenek ve tarih karşısında jakoben tavırları kendi idealist ve ruhçu adesesinden kritik etmiştir. Bu bağlamda Topçu, sonsuz ihtirasların, sefaletlerin, haksızlıkların, düşmanlıkların, maddenin/bedenin hâkimiyetinin sonucu olduğuna inanmaktadır. Ruhu ise, bütün yüce değerleri harekete geçiren, insanı sonsuzluk âlemlerine kanatlandıran, ilimde, iktisatta, sanatta, kültürde ve daha birçok sahada insani olanı ilahi olanla buluşturarak kalbin ve kafanın imtizacını sağlayan bir güç olarak değerlendirmektedir. Madde, çocuksu ilkel heveslerin, şımarık ve nefsanî ihtirasların, şehvet ve şöhretin; ruh ise, insanı hamlıktan olgunluğa yükselten, aşk ve istırabın, kalp ve kafanın yatağıdır. Tam da bu minvalden yola çıkarak diyebiliriz ki, Topçu'nun demokrasi eleştirilerinin de merkezinde madderuh kavramları vardır. Demokrasinin temel sütunları olan eşitlik ve özgürlük değerleri bu açıdan ele alınmaktadır. Demokrasinin özgürlük idealleri hiçbir zaman ruhun hürriyetini amaçlamamıştır. Eşitlik ise insanların ruhen eşit yaratılmadığı "gerçeğini" inkâr ederek, herkeste diğeriyle aklen ve ah- 
laken eşit olduğu vehmini yaratmıs, hürmet ve fazileti zedelemiştir. Ona göre insanın ruhunu, fazilet ve haysiyet doğrultusunda yükseltmeyen her şey muzırdır. İnsan kendi başına terk edilemeyecek kadar irşada ve terbiyeye muhtaçtır. Bu durumda çoğunluğu talim ve terbiye edecek mürşitlik payesi sadece belirli bir azınlığa münhasırdır. Herkesin eşitliğinden söz etmek; âlim ile katili, hırsız ile mürşidi aynı kefeye koymak demektir. Hürriyet ise insanın nefsinin buyurganlığ 1 karşısında başıboş hareket etmesinden başka bir şey değildir. Topçu; demokrasinin büyüğe hürmet duygusunu törpülediğini düşünmekte, eşitlik illüzyonuna kapılan avamın kendini irşada muhtaç görmeyerek kibirlendiğine dikkat çekmektedir. İradenin davasını rehber ittihaz edenler için bu durum kabul edilebilir cinsten değildir.

Demokrasinin diğer sacayaklarını da aynı minvalde (madde-ruh ekseninde) kritik eden Topçu, demokrasiyi insanların maddi arayışlarını tatmin etmelerini sağlayan ve manevi tarafların budayan bir sistem olarak da itham etmektedir. Keza demokrasinin "ortak çıkar" kavramının gerçekliğinin şüpheli olduğunu çünkü halkın, cemiyetin selametinden önce kendi menfaatini düşündüğünü ve kendi menfaatinin de çoğunlukla, daha iyi birev/araba/iş/prestij gibi maddi/nefsani amaçlara yönelik olduğunu iddia etmektedir. "Genel irade" kavramının da benzer şekilde, bir çeşit illüzyon olduğunu ima eden yazar, basın ve sermayenin propagandalarıla halkın iradesinin belirli menfaat grupları lehine manipüle edildiğini, genel irade kavramının da gerçekliğe isabetinin şüpheli olduğunu izhar etmektedir. Bu açıdan genel irade veya ortak çıkar gibi kavramlar da halkın çoğunluğunun görüşlerini yani maddi ve nefsanî iştihaları iktidara taşımaktan ibarettir.

Topçu demokrasinin eşitlik, özgürlük, genel irade ve ortak çıkar gibi temel umdelerine eleştirel yaklaşarak bir tür yönetim biçimi olarak sunduğu irade rejiminin işaretlerini de verir. İnsanlar arasında kültür eşitliğinin olmadığına, hürriyetin ise ahlaken ve ruhen imkânsız olduğuna ve halkın egemenliğinin palavra olduğuna inanan Topçu, demokrasi adı altında halkı aldatan, belirli bir zümrenin çkarlarına hizmet eden, ahlaki değerleri tarumar eden böylesi rejimden kurtulmanın yolunun, fertlerin hürriyetlerinin sınırlandırıldığı otoriteye dayanan milliyetçi sosyalizminden geçtiğini düşünür. Bu ise, olgun ve faziletli bir münevver zümre tarafından idaresinin sağlandığı irade rejimine tekabül eder. 


\title{
EXTENDED ABSTRACT
}

\section{As a Conservative Philosopher Topçu's Approach to the Democracy}

\author{
Yunus Koç \\ Muş Alparslan University
}

Conservatism in Europe; can be evaluated as a kind of reaction ideology that emerged as a result of political, social, economic, and cultural upheavals. Conservatism; forms the resistance point of classes and structures that resist revolutionary and transformative impellents. It can be argued that the concern of protecting the eroded values, and the institutions to be liquidated, against the innovations tried to be established under the leadership of the bourgeoisie is the main motive that feeds conservatism. There is not enough evidence to place conservatism on a particular class base in Turkey. It can be thought that the objections raised against the Republican elite, which considers traditional values as the main reason for the country's backwardness during the modernization process, constitute the source of 'Turkish conservatism'. At this point, as a conservative Turkish thinker, Nurettin Topçu's approach to democracy in the axis of spirit and matter with an idealist philosophy is important.

In this context, the study aims to reveal how Topçu, as a conservative thinker, evaluates the democratic regime with its basic principles and what kind of an ideal form of administration it defends in accordance with the content analysis method.

Conservatism is considered as a kind of ideology aimed at preserving traditional values against radical changes that emerge with modernity. The emphasis on values and norms that will ensure historical continuity is the main outline of this ideology. In Europe, although there are differences between the Anglo-Saxon and Continental European traditions in terms of the content of conservatism, there are common points that will enable us to consider both forms of interpretation as conservative thoughts. It can be said that the considerations such as the distance to the values or redefining the values which are flagged by the French revolution such as; pessimistic approach to human nature, doubting the decisions made by the majority, emp- 
hasis on the importance of institutions that will reproduce social relations especially the family, general will, common interest, freedom, and equality; forms the main lines of the conservative ideology.

As a conservative thinker, Nurettin Topçu brought criticism to similar themes and criticized the Jaccoben attitudes towards tradition and history from his idealistic and spiritual lens. In this context, Topçu believes that endless passions, misery, injustice, and hostility is the result of domination of matter/body. On the other hand, he considers the spirit as a force that activates all the supreme values, envelops the human into the realms of eternity, and as a force that harmonizes the heart and head of the mind by bringing the human to the divine in science, economics, art, culture, and many other fields. In other words, the matter is the bed of childish primitive desires, sassy and selfish ambitions, lust and fame and the soul is the bed of love and suffering, the heart and the head, which raises a man from rawness to maturity. In this manner, we can say that the concepts of matter and soul are placed at the center of Nurettin Topçu's criticisms of democracy. Democracy's ideals of freedom have never aimed the freedom of the soul. On the other hand, equality, has denied the "truth" that people are not created spiritually equal and this has created suspicion that everyone is mentally and morally equal with each other, therefore, respect and virtue have been damaged. According to the Topçu, everything which does not improve the human soul in accordance with virtue and honor is harmful. The human being is in need of a path of truth and discipline that cannot be abandoned by himself. In this case, mentoring incumbency that will execute education and morality on the majority is exclusive only for a certain minority. Speaking of the equality of everyone means that to put the wise and murderer, the thief and mentor on the same scale. On the other hand, Independence is nothing more than a human's stray movement in the face of authoritative of his desire. Topçu believes that democracy has decreased the feeling of respect for the elders, and he also points out that the people who had mired the illusion of equality are not seeing themselves in need of to be shown the path of truth. This situation is not acceptable for those who consider the plea of the will as a guide.

Topçu, criticizing the other trivets of democracy in the same way (in the axis of matter-spirit), also accuses democracy as a system that enables people to satisfy their material pursuits and truncates their spiritual sides. Li- 
kewise, he claims that the reality of the concept of "common interest" of democracy is doubtful because the people think about their own interests before the welfare of the society and that their own interests are mostly aimed at material/egoistic purposes such as a better house/car/job/prestige. Similarly, the author implies that the concept of "general will" is a kind of illusion, and that the will of the people is manipulated in favor of certain interest groups with the propaganda of the press and capital, and that the concept of the general will is doubtful. From this point of view, concepts such as a general will or common interest consist of carrying the views of the majority of the people, that is, material and self-righteous interests, to power.

Topçu gives the signs of the will regime, which it presents as a form of government, by approaching the basic hopes of democracy such as equality, freedom, a general will, and common interest. The author believes that there is no cultural equality between people, freedom is morally and spiritually impossible, and the sovereignty of the people is bragging. Topçu thinks that the way to get rid of such a regime, which deceives the people under the name of democracy, serves the interests of a certain group, and destroys moral values, is through nationalist socialism based on the authority where the freedom of individuals is restricted. This corresponds to a regime of will governed by a mature and virtuous intellectual class.

\section{Kaynakça / References}

Akkaş, H. H. (2003). Muhafazakâr siyasi düşünce kavrami üzerine. Afyon Kocatepe Üniversitesi Sosyal Bilimler Dergisi, 4(2), 241-254.

Aydoğdu, H. (2009). 'Ahlâk filozofu' ve 'hareket adami' olarak Nurettin Topçu. A.Ü. Türkiyat Araştrrmaları Enstitüsü Dergisi. 40, 439-462.

Aytaç, A. M. (2014). Dünya görüşü ve ideoloji. Y. Taşkın (Der.). Siyaset: kavramlar, kurumlar, süreçler içinde (s.107-137). İstanbul: İletişim Yayınları.

Beneton, P. (2011). Muhafazakârlk. Çev., C. Akalın. İstanbul: İletişim Yayınları.

Birgül M. F. (2016). Nurettin Topçu, bugüne ve bize ne söyler?. M.K. Arıcan, M. Orçan, M. E. Kala (Edt.). 40 yil sonra Nurettin Topçu: Nurettin Topçu bugün bize ne söyler içinde (s.65-74.). Ankara: Türkiye Yazarlar Birliği Yayınları.

Burke, E. (2016). Fransa'daki deorim üzerine düşünceler. İstanbul: Kadim Yayınları.

Develioğlu, F. (2015). Osmanlıca-Türkçe Ansiklopedik Lûgat. Ankara: Aydın Kitabevi. 
Güler, E. Z. (2012). Muhafazakârlık: kadim geleneğin savunusundan faydacılığa. B. Örs (Der.). 19. yüzyıldan 20. yüzyıla modern siyasal ideolojiler içinde(ss.115-162). İstanbul: İstanbul Bilgi Üniversitesi Yayınları.

Honderich, T. (2005). Conservatism: Burke, Nozick, Bush, Blair?. London: Pluto Press.

İşler, A. (2019). Türkiye'de Muhafazakâr düşüncede Milliyetçilik(1939-1970). Dokora Tezi. İstanbul Üniversitesi Sosyal Bilimler Enstitüsü, İstanbul.

Kara İ. (2016). Ahlak davasina ve muallimliğe adanmiş bir ömür: Nurettin Topçu. Temaşa Erciyes Üniversitesi Felsefe Bölümü Dergisi, 4(4), 6-23.

Koçak, A. ve Arun, Ö. (2016). İçerik analizi çalişmalarinda örneklem sorunu. Selçuk Üniversitesi Illetişim Dergisi, 4(3), 21-28.

Köni, H. ve Nişancı, E. (2018). Muhafazakâr düşüncede yönetim anlayişi: 18. yy.'dan 20. yy.'in başlarına. Muhafazakâr Düşünce Dergisi. 40, 61-78.

Mollaer, F. (2016). Tekno Muhafazakârlı̆̆ın eleştirisi: Politik denemeler. İstanbul: İetişim Yayınları.

Mollaer, F. (2017). Liberal muhafazakârlik karşisinda Nurettin Topçu. İstanbul: Dergah.

Moore, B. (2016). Diktatörlüğ̈̈n ve demokrasinin toplumsal kökenleri. Ankara: İmge Kitabevi Yayınları.

Öğün, S. S. (1991). Nurettin Topçu'nun siyasal düşüncesinde popülizm-milliyetçilik etkileşimi. Doktora Tezi, Uludağ Üniversitesi Sosyal Bilimler Enstitüsü, Bursa.

Şen, H. (2016). Nurettin Topçu'nun Türk düşüncesindeki sıradışı yeri. Ü. Bozyer (Edt.). Kültür dünyamızın mimarlan içinde (s.35-70.). Muğla: Sıtkı Koçman Üniversitesi Yayınları.

Şeyhanlığlu, H. (2011). Siyasal muhafazakârlığın temel ilkeleri. Dicle Üniversitesi İktisadi ve İdari Bilimler Fakültesi Dergisi. 1(1), 84-107.

Topçu, N. (1947). İradenin davası. Hareket Dergisi. 3(14), 3-5.

Topçu, N. (1948). Devlette İrade. Hareket Dergisi. 3(33), 2-3.

Topçu, N. (1997). Türkiyénin maarif dâvası. İstanbul: Dergah Yayınları.

Topçu, N. (2008). Ahlâk nizâmı. İstanbul: Dergah Yayınları.

Topçu, N. (2011). Bergson. İstanbul: Dergah Yayınları.

Topçu, N. (2013). Sosyoloji. İstanbul: Dergah Yayınları.

Topçu, N. (2014a). Iradenin dâvasi devlet ve demokrasi. İstanbul: Dergah Yayınları.

Topçu, N. (2014b). Psikoloji. İstanbul: Dergah Yayınları.

Topçu, N. (2016). Kültür ve medeniyet. İstanbul: Dergah Yayınları.

Topçu, N. (2017). Yarnkki türkiye. İstanbul: Dergah Yayınları.

Türk, H. B. (2003). İdeoloji. M. Türköne (Der.). Siyaset içinde (s.105-145.). Ankara: Lotus Yayınları. 
Uluçakar, M. (2018). Muhafazakâr demokrasi söylemi üzerine bir inceleme. Alternatif Politika. 10(3), 349-373.

\section{Kaynakça Bilgisi / Citation Information}

Koç, Y. (2020). Muhafazakâr bir düşünür olarak Topçu'nun demokrasi yaklaşımı. OPUS-Uluslararası Toplum Araştırmaları Dergisi, 16(Eğitim ve Toplum Özel Sayıs1), 6318-6343. DOI: 10.26466/opus.718211 